\title{
EDITORIAL
}

\section{LEST WE FORGET! PRESENTATION OF THE SPECIAL ISSUE "RACIAL DIMENSIONS IN THE CORPORATE WORLD"}

\author{
Para não mais esquecer! Apresentação do número especial \\ "A questão racial no mundo empresarial"
}

Pedro Jaime*

Paula Barreto**

Cloves Oliveira***

\begin{abstract}
t can be safely said that research on racial issues has been present in the field of the Social Sciences in Brazil for over a century, if we take the work of Nina Rodrigues, which dates back to the end of the 19th century, as a reference point (CORRÊA, 1998; GONÇALVES DA SILVA, 2002; MUNANGA, 2009). Moreover, the theme has conquered a prominent position in graduate and post-graduate courses and also in journals in this area in our country, labelled either as Sociology of Race Relations, Anthropology of African-Brazilian Populations, or Ethnic and Racial Studies.
\end{abstract}

Notwithstanding, in Brazilian society this theme has been largely forgotten in the field of Management Science. Some authors have already pointed to this fact. Costa and Ferreira (2006), for instance, argued that the racial dimension represents one of the biggest lacunae in the studies on diversity carried out by Brazilian researchers in the area of management, while Conceição (2009) denounced the denial of race in organizational studies in our country. Writing some years later, Rosa (2014) confirmed the existence of such a void. $\mathrm{He}$ also emphasized that Brazilian researchers who investigate diversity management still address racial issues by establishing an almost exclusive dialogue with American researchers, ignoring our national theoretical production in Sociology and Anthropology. From his point of view, this is a major mistake to be rectified in the area of organizational studies. It is true, however, that the emergence of the subject of diversity management has awoken researchers in the area of Management in Brazil to racial issues (FLEURY, 2000; ALVES; GALEÃO-SILVA, 2004).

\footnotetext{
* Professor do Programa de Pós-graduação em Administração do Centro Universitário Fundação Educacional Inaciana Padre Sabóia de Medeiros (FEI), Doutor em Antropologia Social pela Universidade Estadual de São Paulo (USP). E-mail: pedrojaime@fei.edu.br

** Professora da Faculdade de Filosofia e Ciências Humanas da Universidade Federal da Bahia (FFCH/UFBA), Doutora em Sociologia pela Universidade Estadual de São Paulo (USP). E-mail: paulacbarr@uol.com.br.

*** Professor da Faculdade de Filosofia e Ciências Humanas da Universidade Federal da Bahia (FFCH/UFBA), Doutor Ciência Política pelo Instituto Universitário de Pesquisa do Rio de Janeiro. E-mail: cloves.luiz@uol.com.br
} 
On the Social Sciences field, however, the corporate world has not been the privileged empiric locus in Brazilian research on racial issues. Or, at least the presence of black people in positions of higher prestige and remuneration in this universe has not been the primary object of investigation. The religions, the cultural and artistic manifestations, such as capoeira and hip hop, identitary resistance, the black social movements, racial inequalities in a broader sense and, more recently, the affirmative action policies for racial inclusion in higher education have occupied the research agenda of this field in our country. Consequently, the mechanism of racism production in the corporate world in Brazil, and the options as to how to fight it, remain unknown.

Strictly speaking, racial issues in the labor market have already been the object of attention of Brazilian social scientists (BARRETO, 1997; CASTRO; BARRETO, 1998). Nevertheless, the main focus was the position of subalternity occupied by the black population in the occupational structure. The phenomenon of African-Brazilians who are positioned in high status jobs has been more investigated in the world of politics than in corporations. This is evident if we remember from the classic book of Oracy Nogueira (1992), until more recent publications (OLIVEIRA, 2008; 2016).

Only recently has the social upward mobility of blacks in organizations, whether public or private, been discussed in studies bordering the Social Sciences and the Management Science in Brazil. Such is the case of studies as Ladeia's (2006) on the social mobility of African descendants in enterprises in the state of São Paulo; Santana's (2009) about blacks who occupy high level positions in the public service in Salvador; Figueiredo's (2012) on black entrepreneurs in the capital of Bahia. It is also the case of studies as Souza's (2015) on the occupational mobility of black people regarding leadership positions in the city of Belo Horizonte (state of Minas Gerais); and Jaime's (2016) about the social trajectories and the professional paths of two generations of black executives in the corporate world in São Paulo.

Taking steps toward advancing in addressing this lacuna, which is simultaneously theoretical and empirical, is fundamental for the development of the national scientific production, considering the centrality of companies in the integration of Blacks in a class society in Brazil (FERNANDES, 2008). Bearing this in mind and taking into consideration the importance of interdisciplinarity for the process of 'maturity' of research in the field of Management Science, the journal Organizações \& Sociedade has generously given us the opportunity to publish the Special Issue "Racial dimensions in the corporate world".

The Call for Papers invited researchers from the fields of management, social and human sciences and related areas to submit proposals. It indicated our goal of accepting articles that undertook theoretical discussions involving key concepts in relation to the topic, such as racism, anti-racism, racial inequalities, racial inclusion, racial diversity in their connections with the corporate world. It also pointed out that contributions that resulted from empirical research on the themes listed below would be welcomed:

a) global, national and subnational sociopolitical contexts that generate demand for racial diversity initiatives on the part of companies, as is the case of the mobilization efforts of anti-racist advocacy transnational networks; federal, state 
or municipal public policies for the promotion of racial equality; and the actions of international organizations in relation to the rights of African descendants.

b) the translation, to different locations, of the discourses and practices related to racial diversity promoted by multinational corporations by virtue of the distinct sociocultural contexts and institutional frameworks observed beyond their home countries.

c) the tensions, conflicts, negotiations and agreements among different actors (governmental, private sector and non-governmental) involved in political debates and public and entrepreneurial initiatives aimed at the inclusion of African descendants in corporations.

d) the social trajectories and professional paths of black men and women in companies (including new immigrants and/or African and Haitian refugees), problematized on the basis of contemporary debates about race, whether or not in intersection with aspects such as class, gender, sexuality and nationality, and/or thought of in terms of inclusion/exclusion experiences in the work environment.

e) the production, circulation and reception of discourses on racial issues by companies when managing their marketing and communication processes with their diverse audiences, including the representations of black men and women conveyed in such discourses and/or publicized in different media.

In epistemological and theoretical-methodological terms, the aim was to incorporate analyses that concentrated on both the macrosocial level, that is, in the societal context, and analyses that privileged the microsocial level, related to the subjects' lives, albeit always dialoguing with the meso level, which concerns the organizational dynamics and management practices. Equally valued were texts resulting from investigations that adopted quantitative, qualitative or multimethod strategies. Finally, we wanted to embrace analyses involving racial issues in the corporate world grounded on varied theoretical lenses, or that involved exercises of reflexivity, that is, contributions that addressed the standpoint of the researcher in an academic world as the Brazilian one, which Carvalho (2006) had already reported as being characterized by racial confinement and, we would add, as being gendered.

The scientific communities in the fields of management, social and human sciences and related areas responded most positively to our invitation. This can be attested by the number of articles that were submitted: 46 in total! Thus, selecting the contributions that are now part of the present Special Issue became a complex and extenuating endeavor. This task has been successfully accomplished thanks to the support of the editor, professor Ariádne Rigo; the journal's secretary, Tamires Lordelo; and the colleagues responsible for the reviews. We believe that after the desk review of all texts and subsequent double blind peer review of the selected ones, we were able to assure the diversity of contributions, as intended. Among the articles that compose this Issue, there are studies resulting from research that adopted either quantitative or qualitative methodological approaches, which privileged distinct levels of analyses (micro, meso or macro) and that are grounded on different theoretical lenses or epistemological foundations. In addition, it is possible to note that 
the papers are distributed in at least three sub-areas of Management: Organization Studies, Marketing, and Human Resources, with interfaces among them and, in some cases, also in articulation with the area of Public Administration and Government.

The articles in this Special Issue cover a relatively wide spectrum of reflections on racial issues in the corporate world. Some deal with discussions which are classically addressed in the realm of the social sciences, despite bringing updates or some novelty. Others open up new paths for studies on this subject. However, it is necessary to acknowledge that it became clear to us, Guest Editors, - particularly to those of us who have had their educational trajectory, since undergraduates, marked by ethnic and racial studies and who have been doing research on this topic for many years (Cloves Oliveira and Paula Barreto) -, the heterogeneity in the mastery of the literature on race relations in Brazil among the authors of the eight papers that comprise this Issue. This is understandable, since, as we have signaled when opening this presentation, the literature on the topic dates back to the end of the $19^{\text {th }}$ century. Therefore, its domain is not something that is conquered overnight. Following this remark, we want, however, to highlight that if on the one hand interdisciplinarity is crucial to the advancement of scientific knowledge and must be stimulated, on the other, it cannot dispense with an effort to take into consideration the complexity of the discussions held in the heart of each of the disciplines that get in contact with each other.

In the article Wage differentials associated with race between 2002 and 2014 in Brazil: evidence from a quantile decomposition, Gustavo Saraiva Frio and Luiz Felipe Campos Fontes, based on microdata from the National Household Sampling Survey (Pesquisa Nacional de Amostragem Domiciliar - Pnad), and applying the counterfactual Oaxaca-Blinder decomposition method in articulation with the Recentered Influence Function Regression (RIF-Regression) approach, demonstrate that racial inequality in the labor market has persisted, even during the period in which Brazil experienced considerable economic growth. The data revealed that wage differences between whites and non-whites declined very little during the period that was analysed. However, they also showed that the reduction in the salary gap was larger in the higher quantiles of the distribution, that is, the highest-paying jobs. This has been associated with the advancement in years of schooling of the black population. According to the authors, this indicates the possibilities for overcoming the barriers imposed to the social upward mobility of this segment of society, principally through the implementation of quotas for the inclusion of African descendants in higher education.

Nonetheless, the access to higher levels of education does not necessarily guarantee a more qualified insertion of blacks in the labor market. Other factors may prevent African descendants from moving up to positions of more power, prestige and remuneration in the corporate world. This is discussed in the article Judging good appearance in personnel selection, by Altair Santos Paim and Marcos Emanuel Pereira. They analysed the effects of racism on the judgement of 'good appearance' in personnel selection. They used a non-random sample composed by seventy-four (74) participants, forty-two of whom (57\%) were human resources professionals. The data collection instruments were an assessment of résumés, a set of prejudice scales, an inventory of racism in the labor market, an indicator of good appearance and a sociodemographic questionnaire. Three hypotheses were tested and two of them were confirmed: the hypothesis that posited the preference for white candidates and the one that suggested a greater tendency in choosing candidates with a lighter 
complexion. It is then argued that personnel selection should be based on the acceptance of racial diversity, a key element for the creative and innovative development of organizations.

A structural element in the construction process of the nation's images in Brazilian society might hinder the process of overcoming racism when recruiting and selecting personnel. We are referring to the myth of racial democracy. This is the object of discussion in the article by Celso Machado Junior, Roberto Bazanini and Daielly Melina Nassif Mantovani Ribeiro. In The myth of racial democracy in the labor market: a critical analysis of the participation of afro-descendants in brazilian companies, the authors present the results of an investigation where they sought to analyse the opportunities for black people in terms of employability and career mobility in our country. To reach the objective, they carried out a documentary research which involved 117 organizations, which are among the 500 largest companies in Brazil. The results evidenced that racial democracy is indeed a myth in our society, therefore the need to promote social policies that minimize inequalities between whites and blacks, mainly concerning prominent positions in organizations, associated with practices that stimulate diversity in companies.

Aside from placing obstacles in the way of African descendants' career lattice, the racial democracy myth is also present at the other extreme of the occupational structure. That is the conclusion that emerges from reading The invisibility of the black population in modern slavery: evidence based on conditions of social vulnerability, by Rodrigo Martins Baptista, Mariana Lima Bandeira and Maria Tereza Saraiva de Souza. The study used socioeconomic, geographic, sociocultural and social vulnerability indicators produced mainly by the reports published by members of the National Pact for the Eradication of Slave Labor Institute (Instituto Pacto Nacional pela Erradicação do Trabalho Escravo - InPACTO) and the public sector. The authors identified a correlation between the variable race/color and modern slavery. And, most importantly, based on Pierre Bordieu, they denounce that black and brown people are the most vulnerable when it comes to performing jobs in conditions that are analogous to slavery, a fact that is naturalized by the dominant ideology that inferiorizes this population due to their phenotypic characteristics and the colonial-enslaving origin of Brazilian society.

It is discomforting to observe that part of the black population that manages to overcome all the barriers ends up internalizing the dominant ideology. This is the aspect the paper Merit is not for everyone: the perception of black managers about their process of career mobility, by Andrea Alcione Souza and Rafaela Cyrino Peralva Dias, invites us to reflect upon. The authors carried out an investigation with 25 black managers and problematized the assumptions, the functionalities and the productive character of the notion of personal merit in the discourse of the interviewees. The results reveal that the subjects' perception of their own process of career advancement carries strong meritocratic traces. Such perception minimizes, or fails to acknowledge, the social, emotional, moral and economic pre-conditions that influence the differential performance of these individuals. The authors add that this perception implies the disqualification of any argument that reinforces the acknowledgement of the presence of racial barriers in the path of upward social mobility, a fact that contributes to conceal the political, economic and social dimension of racism in our country. 
However, if overcoming racial inequalities is not evident, as the idea of a paradise of inter-racial coexistence is inscribed in the imagination processes of the Brazilian nation, neither is the perpetuation of racism the inexorable destiny in our country. Efforts directed toward the transformation of such a reality have always accompanied our history and are still in action. Concerning this topic, the article Black entrepreneurship and ethnic beauty salons: possibilities for resistance in the social (re)construction of black identity, by Ana Flávia Rezende, Flávia Luciana Naves Mafra and Jussara Jessica Pereira focuses the experiences of five black entrepreneurs who started their own businesses aiming at a clientele whose aesthetics and phenotypic characteristics have been denied for a long time. These enterprises are called ethnic salons and their purpose is to care for black people's curly/ Afro hair. The authors sought to discover the motivations that support these entrepreneurs who fight the logic of coloniality in social relations by starting businesses based on the valorization of black identity. The text contributes to the discussion about hair as a category that represents a constitutive element of racial identity and about the opportunity for a more autonomous insertion of black people in the labor market.

These types of endeavor are even more important when we take into consideration the existence of a veiled racism operating underneath marketing strategies. This is the issue pointed out by the article Selective and 'veiled' demarketing from the perspective of black female consumers. There, Ana Raquel Coelho Rocha and Leticia Moreira Casotti, supported by the literature in demarketing, analyse how black female consumers view marketing actions involving racial issues implemented by companies operating in Brazil. The empiric context investigated is also related to the market of hair beauty and treatment. Based on data from different types of media and from interviews, the authors highlight the existence of a dominant structural pattern, which perpetuates the marginal condition of the natural physical traits of black women. They also signal that the movement toward this consumer's visibility clashes with the fact that these women, even being visibly eager to consume products which value their aesthetics or traits, feel discouraged in relation to their demand.

Despite the importance of economic activities led by black entrepreneurs, it is believed that overcoming racism in Brazil involves debates in the public sphere; debates which are able to influence State and government policies. And, in such debates, the black movement plays a key role. This aspect is approached in the article that closes this Special Issue: World models as organizational models: global framing and transnational activism in the brazilian black movement. In the text, Alexandre Reis Rosa explores the appropriation of diasporic content by the Brazilian black movement. The author departs from the observation that, throughout history, the black diaspora has produced different meanings of what it means to be black, of what racism is and how to fight it. He then discusses how one of these views, the Black Atlantic view, understood as a macrostructure capable of influencing the formation of several frames around the world, underlies the alignment of the Brazilian anti-racist activism to the global framing. In this game, the transnational circulation is articulated with the processes of local adaptation, in a movement that leads to transformations in the discourses of such activism and in relation to the demands it addresses to the political system.

With this set of texts, we hope to have reciprocated professor Rigo's trust, which was demonstrated not only when she welcomed our proposals when we first presented it during our conversation in the Management School at the Federal University of Bahia (UFBA) 
in January 2017, but also by honoring us with their publication in the issue that celebrates the $25^{\text {th }}$ anniversary of this journal. Well, congratulations! 25 years is a symbol of maturity! It is an invitation to review the past and look to the future. Clearly, this kind of endeavor must be undertaken by the competent editor and the journal's editorial staff. However, we would like to make a comment that might help in this process.

This prestigious journal was launched 25 years ago, on the occasion of an annual meeting of Anpad (Associação Nacional de Pós-Graduação e Pesquisa em Administração - National Association of Postgraduation and Research in Administration). At that time, for better or for worse, the organization of such events was not as professional as it came to be. There was a local coordinator for the conference, a professor who was not necessarily directly associated with the board of the entity. In the 1993 Meeting, held in Salvador, this role was assigned to professor Maurício Serva, who was working at UFBA (Federal University of Bahia), and at present is at the Federal University of Santa Catarina. The context then was quite different from the one we are living nowadays. The image of the management scholar was not as disseminated as today. Most of the professors in the area divided their time between teaching undergraduate courses and carrying out consultancy activities, or worked as managers in public or private organizations. Those who worked full time in graduate courses and research were rare.

In that cenario, the young professor Serva, still pursuing his doctorate's degree, decided to create a journal in his School. He raised funds in government entities and private companies, established partnerships and managed to achieve his dream of publishing Organizações \& Sociedade. One of us Guest Editors, Pedro Jaime, who worked as an assistant in his professor's doctorate's research, having developed a strong friendship with him, can vividly remember that moment. He can even recall the meeting professor Serva invited him to participate in, along with the professional who developed the graphic design of the journal: Pedro Belmonte. In times of 'presentism', in which our value is measured only in terms of what we have achieved, and mainly in terms of what we have published over the course of the last three years, sharing these memories so that this history does not fall into oblivion is an act of resistance.

Another event happened to occur during the same period. Equally 25 years ago, the first volume of the book $O$ indivíduo na organização: dimensões esquecidas (CHANLAT, 1993), whose original version, L'individu dans l'organisation: les dimensions oubliées, had been edited a few years before (CHANLAT, 1990), was published. As is well known, the book brings contributions from French authors to a field of Management that, at that time, as still is the case today, is dominated by the English-speaking world, notably the US. In the third volume of the Brazilian edition, published some years later (CHANLAT, 1996), there was an article addressing racism in organizations (VINCENT, 1996). That is to say that, that collection, which had huge repercussion among us, influencing a whole generation of Brazilian professors in the area of management, already drew attention to racial issues.

Why, we may wonder, did it take so long for this dimension to begin, albeit timidly, to be mentioned in publications in the field of management in our country? Such an indignation is even more intriguing if we consider the fact that, as we have pointed out more than once herein, racial issues were already present a century ago in studies in the domains of sociology and anthropology, since the establishment of those areas in our country. Considering 
that, our bewilderment grows: why have the doors to reflections on this theme in the field of management remained carefully locked? - as poetically expresses the photograph of our dear Marcelo Reis, who we wish to thank for having lent his talent to value this project. It is true that this containment was not absolute. In the same School of Management at UFBA, and at the same time, the black anthropologist and intellectual Maria de Lourdes Siqueira (1994) was studying the organizational dimensions of the Candomble (African religion practiced in Brazil) influencing a research program about African-Brazilian organizations in Bahia, that was coordinated by professor Tânia Fischer (FISCHER et al., 1993). A program of great importance, which had investigated the specificities of the local reality. But the focus was not the large companies, neither the position of Blacks in the highest-ranking positions in their organizational structure.

Evidently, answering such complex questions is beyond the scope of this text. We would like, however, to conclude by highlighting that, with the organization of this Special Issue we wish to honor pioneers as professor Maurício Serva and professor Maria de Lourdes Siqueira, and join the efforts that have been invested by black and white researchers who, even meeting resistance, have forged alliances and sought to place the racial dimension in the agenda of the field of Management Science. Thus, we praise the commitment of our colleagues, people such as Alexandre Reis Rosa, Eliane Barbosa Conceição, Eloisio Moulin de Souza, Josiane Silva de Oliveira, Juliana Teixeira, Luiz Alex Saraiva, among others. We celebrate the joint effort, the collective production, the interdisciplinarity, the dialogue between the fields of management and the social sciences. And we invite all of us to permanently reflect on the presence of the racial dimension not only in our studies and research, but in the very organization of our scientific community. Lest we forget!

\section{REFERENCES}

ALVES, M. A.; GALEÃO-SILVA, L. G. A crítica da gestão da diversidade nas organizações. Revista de Administração de Empresas, v. 44, n. 3, 2004.

BARRETO, P. Negros à luz dos fornos: representações do trabalho e da cor entre metalúrgicos baianos. São Paulo: Dynamis Editorial, 1997.

CARVALHO, J. J. de. O confinamento racial do mundo acadêmico brasileiro. Revista da USP, n. 68, 2005-2006.

CASTRO, N. A.; BARRETO, V. S. Trabalho e desigualdades raciais: negros e brancos no mercado de trabalho em Salvador. São Paulo: Anablume, 1998.

CHANLAT, J.-F. (ed.). L'individu dans l'organisation: les dimensions oubliées. Québec: Les Presses de l'Université Laval et Les Editions Eska, 1990.

O indivíduo na organização: dimensões esquecidas. São Paulo: Atlas, 1993. v. 1. . 0 indivíduo na organização: dimensões esquecidas. São Paulo: Atlas, 1996. v. 3.

CONCEIÇÃO, Eliane Barbosa. A negação da raça nos estudos organizacionais. In: ENCONTRO ANUAL DA ASSOCIAÇÃO NACIONAL DE PESQUISA E PÓS-GRADUAÇÃO EM ADMINISTRAÇÃO, 33, São Paulo. 2009. Anais... São Paulo: EnANPAD, 2009. 
CORRÊA, M. As ilusões da liberdade: a escola de Nina Rodrigues e a antropologia no Brasil. Bragança Paulista: EDUSF, 1998.

COSTA, S.; FERREIRA, C. Diversidade e minorias nos estudos organizacionais brasileiros: presença e lacunas na última década. In: ENCONTRO DE ESTUDOS ORGANIZACIONAIS, 4., 2006, Porto Alegre. Anais... Porto Alegre:EnEO, 2006.

FERNANDES, F. A integração do negro na sociedade de classes. São Paulo: Globo, 2008.

FIGUEIREDO, A. Classe média negra: trajetórias e perfis. Salvador: EDUFBA, 2012.

FISCHER, T. et al. Olodum: a arte e o negócio. Revista de Administração de Empresas, v. 33, n. 2, 1993.

FLEURY, M. T. L. Gerenciando a diversidade cultural: experiências de empresas brasileiras. Revista de Administração de Empresas, v. 40, n. 3, 2000.

GONÇALVES DA SILVA, V. Religiões afrobrasileiras: construção e legitimação de um campo do saber acadêmico (1900-1960). Revista USP, n. 55, 2002.

JAIME, P. Executivos negros: racismo e diversidade no mundo empresarial. São Paulo: Edusp-Fapesp, 2016.

LADEIA, R. Acesso e mobilidade profissional de afro-descendentes em empresas paulistas. 2006. Tese (Doutorado em Ciências Sociais), São Paulo, PUC, 2006.

MUNANGA, K. Negros e mestiços na obra de Nina Rodrigues. In: ALMEIDA, A. et al. Religião, Raça e identidade. São Paulo: Paulinas, 2009.

NOGUEIRA, O. Negro político, político negro. São Paulo: Edusp, 1992.

OLIVEIRA, C. L. P. O choque político do ano: a imprensa e a eleição de Celso Pitta para a prefeitura de São Paulo de 1996. Civitas, v. 8, n. 2, 2008.

. Estratégias eleitorais de políticos negros no Brasil na era do marketing político.

Revista Brasileira de Ciência Política, n. 21, 2016.

ROSA, A. R. Relações raciais e estudos organizacionais no Brasil. Revista de Administração Contemporânea, v. 18, n. 3, 2014.

SANTANA, I. À margem do centro: ascensão social e processos identitários entre negros de alto escalão no serviço público - o caso de Salvador. 2009. Tese (Doutorado em Ciências Sociais), Salvador, UFBA, 2009.

SIQUEIRA, M. de L. "Ago Ago Lonan": mito, ritos e organização em terreiros de candomblé na Bahia. Bahia Análise \& Dados, v. 3, n. 4, 1994.

SOUZA, A. A. Cor e ascensão profissional: negros em cargos de comando. Belo Horizonte: Mazza Edições, 2015.

VINCENT, S. Heterofobia e racismo nas organizações. In: CHANLAT, J.-F. (org.). 0 indivíduo na organização: dimensões esquecidas, v. 3. São Paulo: Atlas, 1996. 